\title{
Nano-chitosan coating on maintaining the quality of postharvest chili pepper (Capsicum frutescens $\mathbf{L}$.)
}

\author{
Noor Laila Safitri ${ }^{1}$, Erma Prihastanti ${ }^{1 *}$, Sri Widodo Agung Suedy ${ }^{1}$, Agus Subagio $^{2}$ \\ ${ }^{1}$ Department of Biology, Faculty of Science and Mathematics, Universitas Diponegoro \\ Jl. Prof. Sudarto No.13, Tembalang, Semarang, Central Java, Indonesia. 50275 \\ *Email: eprihast@yahoo.co.id \\ ${ }^{2}$ Department of Physics, Faculty of Science and Mathematics, Universitas Diponegoro \\ Jl. Prof. Sudarto No.13, Tembalang, Semarang, Central Java, Indonesia. 50275
}

\begin{abstract}
Chili pepper (Capsicum frutescens L.) is a horticulture product with a limited shelf life due to quality degradation following harvest. One method of preserving the quality of chili peppers can be evaluated by using nano-chitosan, which combine chitosan and sodium tripolyphosphate (STPP) in certain ratio. The purpose of this study was to determine the impact of nano-chitosan on maintaining the quality of $C$. frutescens L., the optimal ratio of chitosan to STPP for preserving the quality of $C$. frutescens L. after harvest, and the shelf life of $C$. frutescens L. treated with nano-chitosan after harvest. This study employed a completely randomized design (CRD) and included four treatments: P0 (control), P1 (0.2\% nano-chitosan, 1:3 ratio), P2 (0.2\% nano-chitosan, 1:4 ratio), and P3 (0.2\% nano-chitosan, 1:5 ratio), which conducted for 16 days. Weight loss, water content, texture, color, and percentage of damage are the research variables in this study. The ANOVA test was used to examine the data, followed by the DMRT test. The results indicated that nano-chitosan could maintain the weight, water content, texture, and color of chili peppers. The optimal ratio of chitosan to STPP to retain the quality of postharvest $C$. Frutescens L. is $0.2 \%$ nano-chitosan (chitosan: STPP=1:5), and nano-chitosan can maintain the quality of $C$. Frutescens $\mathrm{L}$. for up to 16 days.
\end{abstract}

Keywords: chitosan and sodium tripolyphosphate; chitosan ratio; chroma meter; postharvest storage; shelf life of chili pepper

\begin{abstract}
Article History: Received 3 September 2021; Received in revised form 30 October 2021; Accepted 14 November 2021; Available online 30 December 2021

How to Cite This Article: Safitri NL, Prihastanti E, Suedy SWA, Subagio A. 2021. Nano-chitosan coating on maintaining the quality of postharvest chili pepper (Capsicum frutescens L.). Biogenesis: Jurnal Ilmiah Biologi. vol 9(2): 163-170. doi:
\end{abstract} https://doi.org/10.24252/bio.v9i2.23524.

\section{INTRODUCTION}

Chili pepper (Capsicum frutescens L.) is a commonly cultivated agricultural plant in Indonesia due to its high demand by the public and is frequently used as a complement to Indonesian cuisine spices (Kementerian Pertanian, 2020; Zahara et al., 2021). According to Badan Pusat Statistik (2020), Indonesian chili peppers production reached 1.51 million tons in 2020, an increase of $9.76 \%$ over the previous year. Post-harvest handling of chili peppers is critical for quality preservation hence it extends shelf life, minimizes mechanical and physiological damage, and inhibits the growth of spoilage microorganisms (Rochayat \& Munika, 2015). Post-harvest handling is critical to preserving the chili pepper's quality, including package and storage (da Silva et al., 2015; Ali et al., 2016).

The most common method of postharvest storage is to keep chili peppers at room temperature and to keep them for two-three days (Finger \& Pereira, 2016; Maskey et al., 2021). Chili peppers have a limited shelf life due to their vigorous metabolism when ripe, and microbial spoilages (Edusei et al., 2012). Another way to extend the shelf life of chili peppers is to store them at a temperature of $5^{\circ} \mathrm{C}$, which can keep them fresh for up to 14 days (Maharani et al., 2019). However, this storage strategy may cause chilling injury in Capsicum spp., resulting in the product becoming soft, decreased levels of vitamin $\mathrm{C}$, the appearance of holes and coloured patches on the fruit's surface, increased susceptibility to rot, damage to the plasmalemma, and plastid degradation (Wulandari et al., 2012; Kong et al., 2018; O'Donoghue et al., 2018).

Nano-chitosan become solution to protect chili peppers during storage by coating. Nanochitosan will bind to lipids in the fruit's cuticle layer, forming a biofilm that can limit the fruit's respiration rate by modifying the oxygen, carbon dioxide, and ethylene concentrations 
(Gardesh et al., 2016; Xing et al., 2019; Nguyen et al., 2020). Nano-chitosan offers better nutrient uptake, antimicobial, and antifungal properties than regular chitosan (Van et al., 2013; Ramezani et al., 2015), and is also nontoxic and suitable for human consumption (Slamet, 2011; Sivakumar et al., 2021). Nanochitosan is smaller than chitosan, which results in increased antibacterial activity (Pilon et al., 2014). The ratio of chitosan to sodium tripolyphosphate (STPP), which is used to synthesize nano-chitosan by ionic gelation, affects the particle size of nano-chitosan. STPP is a polyanion that reacts with chitosan to create nano-chitosan, not carcinogenic or mutagenic (Triwulandari et al., 2018). The size of the nanoparticles reduces as the amount of STPP utilized increases.

In the previous studies, nano-chitosan coating on Capsicum annuum L. could inhibit vitamin $\mathrm{C}$ loss and weight loss during storage (Slamet, 2011). Lustriane et al. (2018) reported that chitosan-nanoparticles extended the shelf life and maintain quality of Musa acuminata AAA group. In another research group, the application of chitosan nano-coating using STPP extended the shelf life of Capsicum annuиm L. var. grossum (L.) Sendt without loss of weight, and sensory quality (Hu et al., 2020). Information regarding the use of nano-chitosan coatings containing various ratios of chitosan and STPP on $C$. frutescens $\mathrm{L}$. has never been published. This study aims to determine the impact of nano-chitosan on maintaining the quality of $C$. frutescens L., the optimal ratio of chitosan to STPP for preserving the quality of C. frutescens L. after harvest, and the shelf life of $C$. frutescens $\mathrm{L}$. treated with nano-chitosan after harvest. This study is expected to provide a preliminary data on the effect of edible nanochitosan on $C$. frutescens $\mathrm{L}$. Increased fruit storage life is associated with an increase in fruit quality, and hence is projected to contribute to national food security and economic prosperity.

\section{MATERIALS AND METHODS}

Chili peppers (Capsicum frutescens L.) preparation. $C$. frutescens $\mathrm{L}$. is obtained from farmers in Temanggung Regency, Central Java.
Harvesting was carried out on chili peppers aged 90 days after planting (DAP) and harvested in the morning. The chili pepper utilized as a sample was chosen based on the color and size of the fruit, which were similar. The chili pepper utilized is disease-free and has a reddish-orange color with a length of approximately $6 \mathrm{~cm}$ and a width of $0.90 \mathrm{~cm}$.

Nano-chitosan preparation. This study session was conducted in Laboratory of Nanotechnology, Integrated Laboratory of Universitas Diponegoro. Nano-chitosan was prepared using the ionic gelation method. Chitosan $2 \mathrm{~g}$ was dissolved in $1 \mathrm{~L} 1 \%$ acetic acid, then homogenized for $2 \mathrm{~h}$ using a shaker, then $0.1 \%$ sodium tripolyphosphate (STPP) was added dropwise to form a nanoparticle suspension. Chitosan and STPP were mixed in a ratio of 1:3, 1:4, and 1:5; after STPP was added to the chitosan solution, stirring was continued for $1 \mathrm{~h}$. The crosslinking process was complete the resulting particles were stable.

Nano-chitosan coating treatment. Chili peppers were dipped for $2 \mathrm{~min}$ in a basin containing a solution of nano-chitosan, after which they were removed and dried for approximately $15 \mathrm{~min}$ (Slamet, 2011). Treatment of P1, P2, and P3 were dipped in each $0.2 \%$ nano-chitosan using various ratio (chitosan:STPP) 1:3, 1:4, and 1:5, respectively. Control didn't get any coating treatment.

Chili peppers storage. Chili peppers were stored in perforated cardboard measuring $10 \times 10 \mathrm{~cm}$. Each cardboard box was packed with $30 \mathrm{~g}$ of chili peppers and then stored for 16 days at $29-30^{\circ} \mathrm{C}$ and $30 \% \mathrm{RH}$.

Calculation of weight loss. Weight loss was determined by weighing chili peppers every three days. The formula for calculating weight loss as follows (Meyer, 1932; Davis \& Hofmann, 1973):

weight loss $(\%)=\frac{\mathrm{Wi}-\mathrm{Wf}}{\mathrm{Wf}} \times 100$

Notes:

W0 $=$ initial weight of storage $(\mathrm{g})$

$\mathrm{Wn}=$ weight on day $\mathrm{n}(\mathrm{g})$

Determination of water content. A moisture balance tool (Hitachi, STA200RV) was used to determine the water content of chili peppers. After calibrating, the temperature was 
set to $100^{\circ} \mathrm{C}$, then loaded with $1 \mathrm{~g}$ of chili peppers extract. After $30 \mathrm{~min}$, the water content findings were displayed on the moisture balance tool. The water content unit of a chili pepper was expressed as a percentage.

Texture determination. The texture analyzer tool (LLOYD Instruments/Ametek TA1) was used to determine the texture of chili pepper. The chili pepper was placed on the test table, followed by the probe installation, the computer's single hardness program was then selected, the probe pressure speed, pressure depth, and probe depth to the chili peppers were all set. Following that, the start button was hit, and the resulting texture was printed on the computer.

Color determination. The color of the chili pepper was determined using a chroma meter (Konica Minolta, CR-400 Head). Using white calibration, the chroma meter was produced and calibrated in advance. Chili peppers had been prepared and placed directly in front of the detector. The start button was pressed to initiate the test, and the results will be displayed on the device's display screen. The total color can be calculated as follows (CIE, 1976; Lamona et al., 2015; Putri et al., 2020):

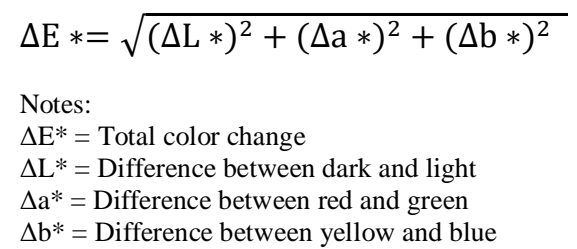

Damage percentage. The level of damage was obtained by calculating the number of chili peppers that were damaged and the number of chili peppers stored. The percentage of chili peppers damage as follows (Abou-Aziz et al., 1974; Putri et al., 2020):

$$
\begin{aligned}
& \text { Damage }(\%) \\
& =\frac{\text { Number of damaged chili peppers }}{\text { Number of chili pepper stored }} \times 100
\end{aligned}
$$

Shelf life of chili peppers. To determine the shelf life of chili pepper that is suitable for consumption is assessed qualitatively by examining the performance of chili pepper, which still looks fresh and has not faded. In addition, the age estimation test was terminated when the chili peppers were still fresh, as shown by a crack sound when they were broken (Kementerian Pertanian, 2019).

Data analysis. The observational data were then examined using analysis of variance (ANOVA) at a $95 \%$ confidence level. If there is a significant effect, additional testing using Duncan's Multiple Range Test is performed (DMRT).

\section{RESULTS AND DISCUSSION}

The nano-chitosan coating on Capsicum frutescens $\mathrm{L}$. had a significantly different effect on the quality during storage $(\mathrm{p} \leq 0.05)$ than the control (Table 1). This layer acts as a barrier between the outer atmosphere and the internal gas composition, inhibiting and modifying gas exchange. $C$. frutescens $\mathrm{L}$. stomata with a diameter of $\pm 10 \mu \mathrm{m}$, and when it is dipped, nano-chitosan can enter and close the stomata pores. The smaller the nano-chitosan particle size, the greater the absorption into the fruit cells and the more effectively the nano-chitosan particles cover the stomatal pores. Following that, the nano-chitosan coats the cuticle layer, allowing the fruit to have a slower rate of respiration, transpiration, and microbial growth. This coating has a beneficial effect on a variety of $C$. frutescens L. quality parameters, including weight, water content, texture, color, and damage.

Effect on weight loss of $C$. frutescens $\mathrm{L}$. Fresh fruit and vegetable weight loss is mainly impacted by the loss of water through respiration and transpiration (Castellanos et al., 2016; Romanazzi et al., 2017). According to table 1 , chili peppers lost $68.2 \%, 70.8 \%$, and $66 \%$ of their weight after 16 days in treatments $\mathrm{P} 1, \mathrm{P} 2$, and $\mathrm{P} 3$, respectively. P0 loses a lot of weight due to the lack of a barrier between the product and the environment. The respiration and transpiration processes are accelerated, resulting in rapid weight loss for the product. Sugars and other substrates such as lipids and proteins are transformed to carbon dioxide, water vapor, and energy during respiration, while the by-products of respiration are removed through evaporation (transpiration)(Tkemaladze \& Makhashvili, 2016; Otoni et al., 2017). Treatments P1, P2, 
and $\mathrm{P} 3$ resulted in less weight loss than $\mathrm{P} 0$ due to the nano-chitosan coating acting as a barrier to gas entry and escape. The nano-chitosan coating may reduce the rate of respiration and transpiration. Our findings corroborate with Slamet (2011), red chilies that were not treated with nano-chitosan lost the most weight when compared to curly chilies that were coated with nano-chitosan. Previous studies reported similar results regarding the weight loss of fruit coated with nano-chitosan (Eshghi et al., 2014; Meena et al., 2020).

Table 1. Effect of nano-chitosan coating on the quality of Capsicum frutescens L. after storage.

\begin{tabular}{lllll}
\hline Treatment & $\begin{array}{l}\text { Weight } \\
\text { loss } \\
(\%)\end{array}$ & $\begin{array}{l}\text { Water } \\
\text { content } \\
(\%)\end{array}$ & $\begin{array}{l}\text { Texture } \\
(\mathrm{gf})\end{array}$ & $\begin{array}{l}\text { Damage } \\
(\%)\end{array}$ \\
\hline P0 & $79.8^{\mathrm{a}}$ & $33.6^{\mathrm{a}}$ & $3304.2^{\mathrm{b}}$ & $46.0^{\mathrm{a}}$ \\
P1 & $68.2^{\mathrm{b}}$ & $26.0^{\mathrm{b}}$ & $4522.4^{\mathrm{a}}$ & $24.0^{\mathrm{b}}$ \\
P2 & $70.8^{\mathrm{b}}$ & $21.3^{\mathrm{b}}$ & $4877.6^{\mathrm{a}}$ & $26.0^{\mathrm{b}}$ \\
P3 & $66.0^{\mathrm{b}}$ & $27.3^{\mathrm{b}}$ & $4351.6^{\mathrm{a}}$ & $20.0^{\mathrm{b}}$ \\
\hline
\end{tabular}

Notes: Numbers followed by the same letter in the same column are not significantly different based on the DMRT test at the level of $95 \%$.

Effect on water content of $C$. frutescens L. C. frutescens L. water content decreased when stored at $29-30^{\circ} \mathrm{C}$, as high temperatures and low humidity accelerate product respiration and water loss. On the first day, the water content of chili pepper was $80 \%$ t, but by the $16^{\text {th }}$ day, P1, P2, and P3 had water content values of $26 \%, 21 \%$, and $27 \%$, respectively, while P0 (control) had a water content value of $33 \%$ (Table 1). It demonstrates that the $C$. frutescens L. coated with nano-chitosan contained less water than the control. P0 contains more water than $\mathrm{P} 1, \mathrm{P} 2$, or $\mathrm{P} 3$ due to increased respiration. The process of respiration involves oxygen reacting with organic molecules in the tissue, resulting in the production of carbon dioxide and water. Because the nano-chitosan layer covering the C. frutescens $\mathrm{L}$. pores was selectively permeable to oxygen, the nano-chitosan coating slowed down their respiration process. The DMRT test findings indicate that P1, P2, and P3 are not statistically different. This is achievable because the nano-chitosan employed in each experiment has the identical concentration of $0.2 \%$, rendering the results insignificant in comparison to one another. Our study discovered the best outcomes in $\mathrm{P} 3$ due to the fact that the nano-chitosan utilized was $200 \mathrm{~nm}$ smaller than the nano-chitosan used in P1 and $\mathrm{P} 2$. The more the amount of STPP added, the smaller the nano-chitosan size. According to Kumar et al. (2017), chitosan applied as a fruit coating will cover the pericarp and stomata layers, hence reducing the rate of respiration and transpiration through the pores. In line with Lustriane et al. (2018), coating fruits with chitosan results in the formation of a layer on the fruit's surface that is selectively permeable to carbon dioxide and oxygen gases. This layer functions as a barrier, preventing and altering gas exchange between the external atmosphere and the internal gas composition, hence inhibiting the transpiration process.

Effect on texture of $C$. frutescens $\mathbf{L}$. According to Table 1, C. frutescens $\mathrm{L}$. coated with nano-chitosan had a lesser texture drop than controls due to its capability to inhibit cell wall disintegration on the fruit surface. $\mathrm{P} 0$ has a lower texture value than $\mathrm{P} 1, \mathrm{P} 2$, and $\mathrm{P} 3$, which all have a texture value of 3304 gf, since P0 softens more quickly due to pectin degradation and oxidation. Wibowo et al. (2020) stated that pectin oxidation results in the release of additional water, causing the texture of the red chili to become soft and wringkled. The texture value increased by $2.6 \%$ in $\mathrm{P} 1$, from 4404.8 to 4522.4 gf, and by $10.7 \%$ in P2, from 4404.8 to $4887.6 \mathrm{gf}$, indicating that the texture of treatments $\mathrm{P} 1$ and $\mathrm{P} 2$ is becoming harder. This is because $\mathrm{P} 1$ and $\mathrm{P} 2$ dry out more quickly than $\mathrm{P} 3$ due to increased transpiration. The particle size of the nano-chitosan used in $\mathrm{P} 1$ and $\mathrm{P} 2$ is larger than in $\mathrm{P} 3,6075 \mathrm{~nm}$ and $247 \mathrm{~nm}$, respectively. As a result, the texture diminishes and becomes dry. Additionally, because the nano-chitosan coating on P1 and P2 did not completely cover the cell surface, their transpiration rates were higher than those of P3. Marganingsih \& Putra (2021) reported that after 15 days of storage, cherry tomatoes coated with $2.5 \%$ shrimp chitosan increased in hardness (texture) value from 35.17 to $37.33 \mathrm{~N}$. The texture value fell by $1.2 \%$ in $\mathrm{P} 3$, from 4404.8 to $4351.6 \mathrm{gf}$. While the textural value of P3 decreases, it still creates a "crack" sound when broken, indicating that the $C$. frutescens 
L. is safe for consumption and marketing. P3 has the most excellent texture compared to $\mathrm{P} 0$, $\mathrm{P} 1$, and $\mathrm{P} 2$ because the nano-chitosan employed is very small, around $200 \mathrm{~nm}$. The smaller the nano-chitosan, the greater its absorption into cells, preventing chitosan's effectiveness in suppressing excessive $\mathrm{CO}_{2}$ production and cell wall disintegration. Shiekh et al. (2013) assert that the texture of the fruit is related to the cell wall structure. During fruit ripening, the cell wall is destroyed. According to Liu et al. (2014), pectin methylesterase (PME) is involved in cell wall breakdown. The activity of the PME is related to $\mathrm{CO}_{2}$ production; once it is inhibited, the movement of cell wall-degrading enzymes will be reduced, allowing the fruit texture to be preserved during storage.

Effect on color of $C$. frutescens L. C. frutescens $\mathrm{L}$. changes color during storage due to the rate of transpiration and respiration. Table 2 shows the brightness values of $\mathrm{C}$. frutescens $\mathrm{L}$. treated with and without nanochitosan. The findings of the Hunter $\mathrm{L}, \mathrm{a}, \mathrm{b}$ method color test in Table 2 indicate that P1, $\mathrm{P} 2$, and $\mathrm{P} 3$ have $\Delta \mathrm{E}$ values of $33.62,24.99$, and 21.37 , respectively. Because a greater $\Delta \mathrm{E}$ value indicates a darker sample color, the data indicates that $\mathrm{P} 3$ has a lighter color. $\mathrm{P} 2$ and $\mathrm{P} 3$ in Fig. 1 have brighter hues than $\mathrm{P} 0$ and $\mathrm{P} 1$. C. frutescens $\mathrm{L}$. are reddish-orange in color due to the presence of carotenoid and anthocyanin pigments, where carotenoids will be degraded by oxodation during storage. Since nanochitosan is selectively permeable to oxygen, it inhibits the carotenoid breakdown process (Salinas-Roca et al., 2018; Haghighi et al., 2020), hence slowing the color shift in C. frutescens $\mathrm{L}$.

Table 2. The color of Capsicum frutescens L. after storage.

\begin{tabular}{lllll}
\hline Treatment & $\mathrm{L}$ & $\mathrm{a}$ & $\mathrm{b}$ & $\Delta \mathrm{E}$ \\
\hline P0 & $26.15^{\mathrm{c}}$ & $21.25^{\mathrm{c}}$ & $19.18^{\mathrm{b}}$ & 38.11 \\
P1 & $29.66^{\mathrm{b}}$ & $24.68^{\mathrm{b}}$ & $21.03^{\mathrm{b}}$ & 33.62 \\
P2 & $34.81^{\mathrm{a}}$ & $27.01^{\mathrm{b}}$ & $27.97^{\mathrm{a}}$ & 24.99 \\
P3 & $37.95^{\mathrm{a}}$ & $31.25^{\mathrm{a}}$ & $29.55^{\mathrm{a}}$ & 21.37
\end{tabular}

Notes: $\mathrm{L}^{*}=$ brightness; $\mathrm{a}^{*}=$ red $\left(+\mathrm{a}^{*}\right)$ and green $\left(-\mathrm{a}^{*}\right) ; \mathrm{b}^{*}=$ yellow $\left.{ }^{(}+\mathrm{b}^{*}\right)$ and blue $\left(-b^{*}\right) ; \Delta E^{*}=$ a total color change. Numbers followed by the same letter in the same column are not significantly different based on the DMRT test at the level of $95 \%$.

Additionally, the delayed color shift of chitosan-coated fruit is mediated by metabolic activity inhibition, which slows anthocyanin breakdown (Kumar et al., 2017). The degradation of anthocyanin is affected by light, temperature, oxygen, and enzymes, which provided by polyphenol oxidase (Cavalcanti et al., 2011). The polyphenol oxidase enzyme catalyzes the hydroxylation of monophenols to produce o-diphenols and the oxidation of odiphenols to produce o-quinones. The nanochitosan coating functions as an oxygen barrier, limiting the action of the polyphenol oxidase enzyme, hence slowing anthocyanin degradation (Zambrano-Zaragoza et al., 2014).

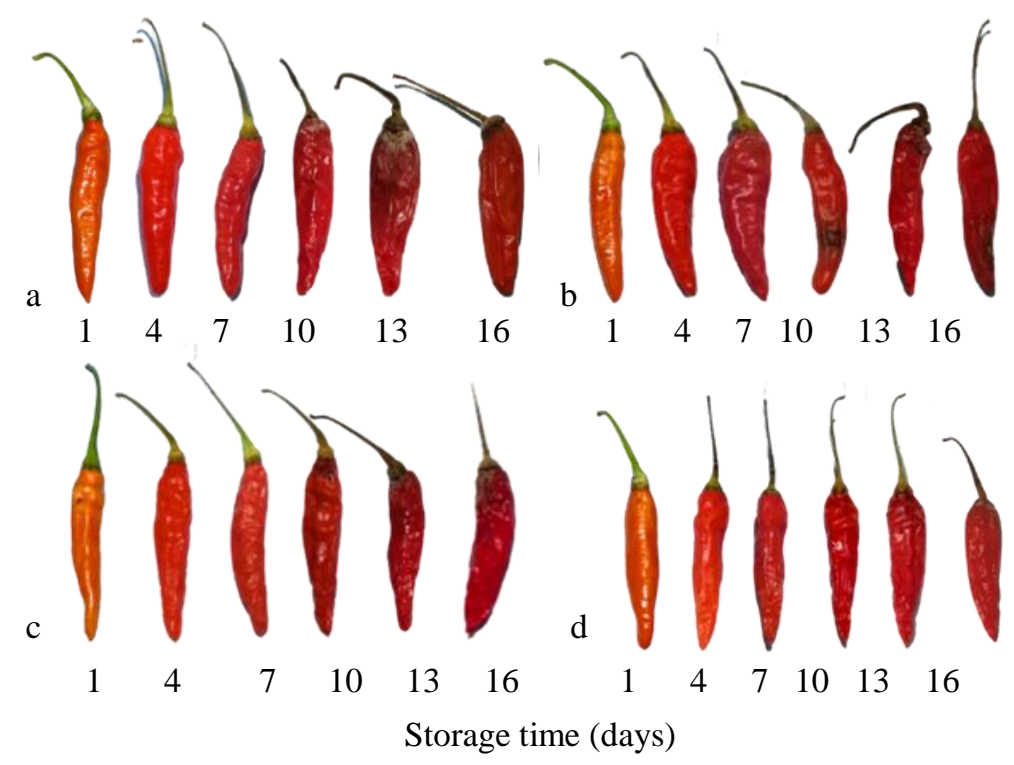

Fig. 1. The color change of Capsicum frutescens L. during 16 days of storage: a. Control; b. P1; c. P2; d. P3. 
Effect on damage percentage of $C$. frutescens $\mathbf{L}$. Our study discovered that $C$. frutescens L. causes chemical and microbial damage. The deterioration began on the $7^{\text {th }}$ day, but after the P3 treatment, the deterioration began on the $10^{\text {th }}$ day. $C$. frutescens $\mathrm{L}$. decreased by $24 \%, 26 \%$, and $20 \%$ on the $16^{\text {th }}$ day of $\mathrm{P} 1, \mathrm{P} 2$, and $\mathrm{P} 3$, respectively. This result is preferable to the control, which causes $46 \%$ of the damage. Due to the antibacterial properties of nano-chitosan, covering fruit with nano-chitosan can help prevent deterioration. According to Raliya \& Tarafdar (2014), nanochitosan has a greater ability to penetrate cells, hence boosting chitosan's performance in cells. P0 treatment obtained the most damage since it lacked any coating to protect quality, allowing microorganisms to quickly colonize the surface of the fruit. Because the nano-chitosan employed as a coating has a small size (200 $\mathrm{nm}), \quad \mathrm{P} 3$ can minimize damage by $51 \%$ compared to control. In line with Pilon et al. (2014), the smaller the particle size, the greater the surface interaction with microbial cells, resulting in an increase in antimicrobial activity. In addition, Gad et al. (2016) stated, chitosan's antibacterial activity is caused by the positive charge of amino acids binding to the negative charge of the microbial cell membrane, increasing its permeability and ultimately causing cell death.

Based on the quality parameters after storage, nano-chitosan can extend the shelf life of $C$. frutescens $\mathrm{L}$. by up to 16 days, specifically using P3. Storage was halted when one of the treatments continued to meet the fresh fruit criteria, specifically when it was damaged and still sounded "crack." It demonstrates that coating with $0.2 \%$ nano-chitosan in a $1: 5$ ratio can extend the shelf life of $C$. frutescens $\mathrm{L}$. by 13-14 days. The coating with nano-chitosan has an effect on all observation parameters (weight loss, water content, texture, color, percentage of damage) of $C$. frutescens $\mathrm{L}$. However, the layer containing $0.2 \%$ nano-chitosan in ratios of $1: 3$, $1: 4$, and 1:5 had no discernible effect on the other layers. Therefore, further research with nano-chitosan at various concentrations and ratios of chitosan to STPP less than 1:3 is necessary.

\section{CONCLUSION}

Nano-chitosan can help maintain the quality of Capsicum frutescens L. after harvesting, including weight, water content, texture, and color. C. frutescens $\mathrm{L}$. coated with $0.2 \%$ nano-chitosan in a $1: 5$ ratio produced the greatest results and retained their quality for up to 16 days after storage. It is preferable to conduct additional research on the antimicrobial activity of nano-chitosan, which inhibits the growth of fungi in $C$. frutescens $\mathrm{L}$.

\section{ACKNOWLEDGEMENTS}

The authors would like to express their gratitude to the Head of Laboratory of Nanotechnology, Integrated Laboratory of Universitas Diponegoro, and the staff for their willingness to carry out the nano-chitosan solutions for this research.

\section{REFERENCES}

Abou-Aziz AB, Abdel-Maksoad MM, Abdel-Samie KA, Abdel-Kader AS. 1974. Comparative effects of chilling injury on three cultivars of tomatoes harvested at maturegreen stage. Gartenbauwissenschaft. vol 39: 191-198.

Ali A, Bordoh PK, Singh A, Siddiqui Y, Droby S. 2016. Post-harvest development of anthracnose in pepper (Capsicum spp): Etiology and management strategies. Crop Protection. vol 90: 132-141. doi: https://doi.org/10.1016/j.cropro.2016.07.026.

Badan Pusat Statistik. 2020. Produksi tanaman sayuran menurut provinsi dan jenis tanaman, 2020. Jakarta: Badan Pusat Statistik, Indonesia. https://www.bps.go.id/.

Castellanos DA, Herrera DR, Herrera AO. 2016. Modelling water vapour transport, transpiration and weight loss in a perforated modified atmosphere packaging for feijoa fruits. Biosystems Engineering. vol 151: 218-230. doi: https://doi.org/10.1016/j.biosystemseng.2016.08.0 15.

Cavalcanti RN, Santos DT, Meireles MAA. 2011. Nonthermal stabilization mechanisms of anthocyanins in model and food systems-An overview. Food Research International. vol 44(2): 499-509. doi: https://doi.org/10.1016/j.foodres.2010.12.007.

CIE. 1976. L*a*b* colour difference. Vienna: Commision Internationale de l'Eclairage. https://cie.co.at/.

da Silva HW, Soares RS, Vale LSR. 2015. Quality of chilli-peppers seeds depending on the fruits postharvest resting. Revista de Ciências Agrárias/Amazonian Journal of Agricultural and Environmental Sciences. vol 58(4): 427-433.

Davis PL, Hofmann RC. 1973. Effects of coatings on 
weight loss and ethanol buildup in juice of oranges. Journal of Agricultural and Food Chemistry. vol 21(3): 455-458. doi: https://doi.org/10.1021/jf60187a026.

Edusei VO, Ofosu-Anim J, Johnson PN, Cornelius EW. 2012. Extending postharvest life of green chilli pepper fruits with modified atmosphere packaging. Ghana Journal of Horticulture. vol 10: 131-140.

Eshghi S, Hashemi M, Mohammadi A, Badii F, Mohammadhoseini Z, Ahmadi K. 2014. Effect of nanochitosan-based coating with and without copper loaded on physicochemical and bioactive components of fresh strawberry fruit (Fragaria $\mathrm{x}$ ananassa Duchesne) during storage. Food and Bioprocess Technology. vol 7(8): 2397-2409. doi: https://doi.org/10.1007/s11947-014-1281-2.

Finger FL, Pereira GM. 2016. Physiology and postharvest of pepper fruits. New York: Springer. pp 27-40.

Gad MM, Zagzog OA, Hemeda OM. 2016. Development of nano-chitosan edible coating for peach fruits cv. Desert Red. International Journal of Environment. vol 5(4): 43-55.

Gardesh ASK, Badii F, Hashemi M, Ardakani AY, Maftoonazad N, Gorji AM. 2016. Effect of nanochitosan based coating on climacteric behavior and postharvest shelf-life extension of apple cv. Golab Kohanz. LWT. vol 70: 33-40. doi: https://doi.org/10.1016/j.lwt.2016.02.002.

Haghighi H, Licciardello F, Fava P, Siesler HW, Pulvirenti A. 2020. Recent advances on chitosanbased films for sustainable food packaging applications. Food Packaging and Shelf Life. vol 26: 1-16. doi: https://doi.org/10.1016/j.fpsl.2020.100551.

Hu X, Saravanakumar K, Sathiyaseelan A, Wang MH. 2020. Chitosan nanoparticles as edible surface coating agent to preserve the fresh-cut bell pepper (Capsicum annuum L. var. grossum (L.) Sendt). International Journal of Biological Macromolecules. vol 165: 948-957. doi: https://doi.org/10.1016/j.ijbiomac.2020.09.176.

Kementerian Pertanian. 2019. Penanganan pascapanen cabai. Lembang: Balai Penelitian Tanaman Sayur, Badan Penelitian dan Pengembangan Pertanian, Kementerian Pertanian Republik Indonesia. https://balitsa.litbang.pertanian.go.id/.

Kementerian Pertanian. 2020. Teknologi pengolahan cabai. Jakarta: Direktorat Jenderal Hortikultura, Kementerian Pertanian Republik Indonesia. http://hortikultura.pertanian.go.id/.

Kong X, Wei B, Gao Z, Zhou Y, Shi F, Zhou X, Zhou Q, Ji S. 2018. Changes in membrane lipid composition and function accompanying chilling injury in bell peppers. Plant and Cell Physiology. vol 59(1): 167178. doi: https://doi.org/10.1093/pcp/pcx171.

Kumar P, Sethi S, Sharma RR, Srivastav M, Varghese E. 2017. Effect of chitosan coating on postharvest life and quality of plum during storage at low temperature. Scientia Horticulturae. vol 226: 104-
109. https://doi.org/10.1016/j.scienta.2017.08.037.

doi:

Lamona A, Purwanto YA, Sutrisno S. 2015. Pengaruh jenis kemasan dan penyimpanan suhu rendah terhadap perubahan kualitas cabai merah keriting segar. Jurnal Keteknikan Pertanian. vol 3(2): 145152. doi: https://doi.org/10.19028/jtep.03.2.\%25p.

Liu K, Yuan C, Chen Y, Li H, Liu J. 2014. Combined effects of ascorbic acid and chitosan on the quality maintenance and shelf life of plums. Scientia Horticulturae. vol 76: 45-53. doi: https://doi.org/10.1016/j.scienta.2014.06.027.

Lustriane C, Dwivany FM, Suendo V, Reza M. 2018. Effect of chitosan and chitosan-nanoparticles on post harvest quality of banana fruits. Journal of Plant Biotechnology. vol 45(1): 36-44. doi: https://doi.org/10.5010/JPB.2018.45.1.036.

Maharani DM, Lastriyanto A, Rafianto V, Putri SVYS, Khasanah K. 2019. Rancang bangun hypobaric storage sebagai alat penyimpanan cabai rawit (Capsicum frutescens L.). Agritech. vol 39(2): 143152. doi: https://doi.org/10.22146/agritech.37230.

Marganingsih A, Putra ETS. 2021. Pengaruh konsentrasi kitosan udang dan kepiting sebagai edible coating terhadap mutu dan daya simpan tomat ceri (Solanum lycopersicum var. Cerasiforme). Vegetalika. vol 10(1): 69-80. doi: https://doi.org/10.22146/veg.53519.

Maskey B, Bhattarai R, Bhattarai G, Shrestha NK. 2021. Post-harvest quality of fresh Akabare chili (Capsicum chinese) as affected by hydrocooling, package modification and storage temperature. International Journal of Food Properties. vol 24(1): 163-173. doi: https://doi.org/10.1080/10942912.2020.1865399.

Meena M, Pilania S, Pal A, Mandhania S, Bhushan B, Kumar S, Gohari G, Saharan V. 2020. Cu-chitosan nano-net improves keeping quality of tomato by modulating physio-biochemical responses. Scientific Reports. vol 10(1): 1-11. doi: https://doi.org/10.1038/s41598-020-78924-9.

Meyer BS. 1932. Further studies on cold resistance in evergreens, with special reference to the possible role of bound water. Botanical Gazette. vol 94(2): 297-321. doi: https://doi.org/10.1086/334299.

Nguyen VTB, Nguyen DHH, Nguyen HVH. 2020. Combination effects of calcium chloride and nanochitosan on the postharvest quality of strawberry (Fragaria x ananassa Duch.). Postharvest Biology and Technology. vol 162: 1-8. doi: https://doi.org/10.1016/j.postharvbio.2019.111103.

O’Donoghue EM, Brummell DA, McKenzie MJ, Hunter DA, Lill RE. 2018. Sweet capsicum: postharvest physiology and technologies. New Zealand Journal of Crop and Horticultural Science. vol 46(4): 269297.

doi: https://doi.org/10.1080/01140671.2017.1395349.

Otoni CG, Avena-Bustillos RJ, Azeredo HMC, Lorevice MV, Moura MR, Mattoso LHC, McHugh TH. 2017. Recent advances on edible films based on 
fruits and vegetables - a review. Comprehensive Reviews in Food Science and Food Safety. vol 16(5): 1151-1169. doi: https://doi.org/10.1111/1541-4337.12281.

Pilon L, Spricigo PC, Miranda M, de Moura MR, Assis OBG, Mattoso LHC, Ferreira MD. 2014. Chitosan nanoparticle coatings reduce microbial growth on fresh-cut apples while not affecting quality attributes. International Journal of Food Science \& Technology. vol 50(2): 440-448. doi: https://doi.org/10.1111/ijfs.12616.

Putri YR, Khuriyati N, Sukartiko AC. 2020. Analisis pengaruh suhu dan kemasan pada perlakuan penyimpanan terhadap kualitas mutu fisik cabai merah keriting (Capsicum annum L.). Jurnal Teknologi Pertanian. vol 21(2): 80-93. doi: https://doi.org/10.21776/ub.jtp.2020.021.02.2.

Raliya R, Tarafdar JC. 2014. Biosynthesis and characterization of zinc, magnesium and titanium nanoparticles: an eco-friendly approach. International Nano Letters. vol 4(1): 1-10. doi: https://doi.org/10.1007/s40089-014-0093-8.

Ramezani Z, Zarei M, Raminnejad N. 2015. Comparing the effectiveness of chitosan and nanochitosan coatings on the quality of refrigerated silver carp fillets. Food Control. vol 51: 43-48. doi: https://doi.org/10.1016/j.foodcont.2014.11.015.

Rochayat Y, Munika VR. 2015. Respon kualitas dan ketahanan simpan cabai merah (Capsicum annuum L.) dengan penggunaan jenis bahan pengemas dan tingkat kematangan buah. Jurnal Kultivasi. vol 14(1): 65-72. doi: https://doi.org/10.24198/kultivasi.v14i1.12093.

Romanazzi G, Feliziani E, Baños SB, Sivakumar D. 2017. Shelf life extension of fresh fruit and vegetables by chitosan treatment. Critical Reviews in Food Science and Nutrition. vol 57(3): 579-601. doi: https://doi.org/10.1080/10408398.2014.900474.

Salinas-Roca B, Guerreiro A, Welti-Chanes J, Antunes MDC, Martín-Belloso O. 2018. Improving quality of fresh-cut mango using polysaccharide-based edible coatings. International Journal of Food Science \& Technology. vol 53(4): 938-945. doi: https://doi.org/10.1111/ijfs.13666.

Shiekh RA, Malik MA, Al-Thabaiti SA, Shiekh MA. 2013. Chitosan as a novel edible coating for fresh fruits. Food Science and Technology Research. vol 19(2): 139-155. doi: https://doi.org/10.3136/fstr.19.139.

Sivakumar D, Gunes NT, Romanazzi G. 2021. A comprehensive review on the impact of edible coatings, essential oils, and their nano formulations on postharvest decay anthracnose of avocados, mangoes, and papayas. Frontiers in Microbiology. vol 12: 1-10. doi: https://dx.doi.org/10.3389\%2Ffmicb.2021.711092.

Slamet R. 2011. Pelapisan cabe merah dengan nanopartikel kitosan untuk menghambat kehilangan vitamin c dan susut bobot. Jurnal Riset Sains dan Kimia Terapan. vol 1(1): 1-8. doi: https://doi.org/10.21009/JRSKT.011.01.

Tkemaladze GS, Makhashvili KA. 2016. Climate changes and photosynthesis. Annals of Agrarian Science. vol 14(2): 119-126. doi: https://doi.org/10.1016/j.aasci.2016.05.012.

Triwulandari E, Fahmiati S, Sampora Y, Meliana Y, Ghozali M, Sondari D. 2018. Effect of polyanions variation on the particle size of chitosan nanoparticle prepared by ionic gelation method. AIP Conference Proceedings. vol 2024(1): 1-6. doi: http://dx.doi.org/10.1063/1.5064314.

Van SN, Minh HD, Anh DN. 2013. Study on chitosan nanoparticles on biophysical characteristics and growth of Robusta coffee in green house. Biocatalysis and Agricultural Biotechnology. vol 2(4): 289-294. doi: https://doi.org/10.1016/j.bcab.2013.06.001.

Wibowo C, Haryanti P, Wicaksono R. 2020. Effect of edible coating application by spraying method on the quality of red chili during storage. IOP Conference Series: Earth and Environmental Science. vol 746: 1-10. doi: https://doi.org/10.1088/1755-1315/746/1/012004.

Wulandari S, Bey Y, Tindaon KD. 2012. Pengaruh jenis bahan pengemas dan lama penyimpanan terhadap kadar vitamin c dan susut berat cabai rawit (Capsicum frutescens L.). Biogenesis. vol 8(2): 2330. doi: http://dx.doi.org/10.31258/biogenesis.8.2.23-30.

Zahara AD, Wisnujati NS, Siswati E. 2021. Analisis produksi dan produktivitas cabai rawit (Capsicum frutescens L.) di Indonesia. Jurnal Ilmiah Sosio Agribis. vol 21(1): 18-29. doi: http://dx.doi.org/10.30742/jisa.v21i1.1345.

Zambrano-Zaragoza ML, Gutiérrez-Cortez E, Del Real A, González-Reza RM, Galindo-Pérez MJ, Quintanar-Guerrero D. 2014. Fresh-cut Red Delicious apples coating using tocopherol/mucilage nanoemulsion: Effect of coating on polyphenol oxidase and pectin methylesterase activities. Food Research International. vol 62: 974-983. doi: https://doi.org/10.1016/j.foodres.2014.05.011. 